weights are given in grammes. They were determined on a Salter's spring balance which carried 500 grammes, and its scale was divided into intervals of 10 grammes each. Icegrains which weighed more than 500 grammes were divided in two.

As has been already pointed out, the figures in the tables do not give an exact statistical account of the blocks of ice. The smallest grains have most frequently escaped being weighed, therefore the average size of the grain comes out higher than the truth. The figures in the tables give a general idea of the constitution or anatomy of a block of ice taken from the lower part of a large glacier. They are particularly interesting when we reflect that every grain, even the largest, has grown, according to the rigid laws of crystallomorphic development, from a single snow crystal which probably weighed no more than one or two centigrammes.

In the Mergelin See, glacier ice can be studied in a way that is possible in no other place. The fragments of the Aletsch Glacier which float in it are veritable icebergs, and behave in the same way as their relatives in the Arctic or Antarctic Ocean. In the middle of summer, however, they are exposed to a much more powerful sun than either the northern or the southern bergs. Consequently, the weathering and disintegration, as well as the melting, proceed at a much more rapid rate.

The action of the sun's rays on glacier ice is twofold ; it disarticulates the ice into its constituent grains, and it splits the individual grain up into laminæ perpendicular to the principal axis of the crystal and bounded by the planes of fusion discuvered and described by Tyndall. These planes are the distinguishing characteristic of the individual ice-grain.

Under the influence of radiant heat an ice-crystal begins to melt at the surfaces which separate these laminæe, and the process of disintegration and decay is directed by their plane. On the other hand, an ice-crystal, floating in water and losing heat, generates ice laminæ which are directed by the same planes, which form the continuation of the corresponding laminæe of the parent crystal. This was well ob:erved at the end of August, 1895. Every night a thin skin of ice was formed at the shallow end of the lake, where the ice blocks are collected. As the grains in a block of glacier ice are distributed quite irregularly, the water line of a fl rating block necessarily cuts a great number of grains, all of which are oriented differently. The ice which was formed during the night along this line was oriented crystallographically by the grain with which it was in contact and from which it appeared to spring in continuation of its crystalline laminx. This produces a remarkable pattern of lines on the surface of the lake ice contiguous to a block of glacier ice.

1 yndall has described and figured the minute features of the disintegration of the crystal under the absurption of radiant heat. Similar and complementary features are observed when ice is generated from an existing crystal under the dissipation of heat. To do justice to them, however, would require the services of a skilful, patient and resourceful artist.

The disarticulating and analysing action of the sun's rays is not accomplished without the selection and expenditure of energy. Accordingly we observe that one grain protects another. The disarticulation into separate grains, although very thorough $\mathbf{n} \pm \mathbf{a}$ the surface of a glacier, does not penetrate far. A stroke or two with an ice axe reveals the fresh blue ice. The analysis of the individual grain into crystallographically oriented laminæe can be particularly well studied in the Mergelin See. It is only the grains that are exposed to the sky, and above water, that are so analysed; and prolonged exposure of this kind reduces a grain to the last stage of dilapidation. The grains beneath the surface, whelher of ice or water, are almost completely unattacked.

The importance, or rather the necessity, of direct sky-light for the disarticulation of glacier ice into its constituent grains is very well seen in the artificial grottoes which are maintained at easily accessible parts of most popular glaciers. The thickness of the layer of completely disarticulated ice is so small that it is hardly noticed, and the whole grotto appears to be cut out of pure blue ice. If the observer, on penetrating for a few paces, turns round and looks outwards, he sees the surface of the ice-walls of the grotto etched with strange line-figures. These are most strongly marked near the opening, and they cease exactly at the spot where the last ray of direct sky-light strikes the ice. The lines so developed are formed by the intersection of the surface of the ice-wall of the cave with the separating surfaces of contiguous ice-grains. The photographic picture thus presented is one of very great interest.

It is only perfectly pure water, received directly as it flows from the still, that can be frozen into homogeneous glass-like ice. All natural ice proceeds from impure water.

In lake ice of moderate thickness the crystalline axis is perpendicular to the surface of the lake. Consequently, Tyndall's planes of fusion are parallel to this surface. When exposed to a powerful sun, and with an air temperature even much below $0^{\circ} \mathrm{C}$., the ice weathers into horizontal laminæe separated by Tyndall's planes of fusion, and into vertical columns. The column in lake ice and the grain in glacier ice are homologous features. They express the form which the individual crystal takes in these different varieties of natural ice.

Were it not for the fact that a glacier is made up of distinct grains of ice, and that this substance has the property of melting and freezing at different temperatures, accurding to the composition of the water with which it comes in contact and to the pressure to which it is subjected, there is little doubt that a glacier would be as motionless as any other mass of crystalline rock.

T. Y. BUCHANAN.

August 6.

\section{Problems of Geometry.}

IN Klein's “Famous Problems of Elementary Geometry," geometrical proofs are given for solving the problems of " the duplication of the cube" and "the trisection of an angle" by means of the cissoid and the conchoid respectively. I find, however, that in "Chambers' Encyclopædia" it is stated, without proof, that the cissoid and the conchoid are capable of furnishing geometrical constructions for the solution of both problems. Can any of your readers furnish me with the necessary references, or supply a proof of the "trisection of an angle" by means of the cissoid, and of the "duplication of the cube" by means of the conchoid?

Fledborough Hall, Holyport, Berks, August 9.

\section{Forecast and Fact.}

IN NATURE of January 12, 1893 (p. 246), I represented as probable an early descent of the smoothed curve of rain days at Greenwich, there given, " and a commencing series of (on the average) drier summers than we have had lately."

The following table may now be compured with this :-

\begin{tabular}{|c|c|c|c|c|c|c|}
\hline & & \multicolumn{3}{|c|}{ Rf. Summer. } & \multicolumn{2}{|c|}{ Relation to av. $(6.8 \mathrm{I})$} \\
\hline 1893 & $\ldots$ & $\ldots$ & $5 \cdot 40$ & $\ldots$ & $\ldots$ & $-I \cdot 4 I$ \\
\hline 1894 & $\ldots$ & $\ldots$ & $8 \cdot 33$ & $\ldots$ & $\ldots$ & $+I \cdot 52$ \\
\hline 1895 & $\ldots$ & $\ldots$ & 574 & $\ldots$ & $\ldots$ & $-1 \% 7$ \\
\hline 1896 & $\cdots$ & $\cdots$ & 5.07 & $\ldots$ & $\ldots$ & $-1 \cdot 74$ \\
\hline 1897 & $\ldots$ & $\ldots$ & $5 \cdot 5^{2}$ & $\ldots$ & $\ldots$ & $-1 \cdot 29$ \\
\hline 1898 &. & $\ldots$ & 3.95 & $\ldots$ & $\ldots$ & $-2 \cdot 86$ \\
\hline I 899 & $\ldots$ & $\ldots$ & 2.85 & $\ldots$ & $\ldots$ & $-3 \cdot 96$ \\
\hline 1900 & $\ldots$ & $\ldots$ & $6 \cdot 26$ & $\ldots$ & $\ldots$ & -0.55 \\
\hline
\end{tabular}

Per contra, there is the chastening reflection that a rule which held good (with one exception) since I8I5 (see Symons' Met. Mag., June 1898 , p. 70), and which was quoted in your columns, has broken down on this occasion, viz. that in the group of five summers ending with a sunspot minimum, there are more wet summers than dry!

A. B. M.

\section{Boomerangs.}

IN relation to the interesting article on boomerangs in your issue of August I, it may perhaps be of interest to some of your readers to know that Schiaparelli, in his famous book, "Entwurf einer astronomischen Theorie der Sternschnuppen," p. 13, speaks of "bumerangs." He says :- "Very likely the cateja described by Isidor of Seviglia was nothing but a sort of bumerang." "Est genus Gallici teli, ex materia quam maxime lenta, qux jacta quidem non longe propter gravitatem evolat, sed quo pervenit, vi nimia perfringit : quod si ab artifice mittatur, rursus redit ad eum qui misit." Isidori Hispalensis, Origg, xviii. Torino (Italy) Via della Rocc 25 s.

NO. I660, VOL. 64] 